\title{
FREQUENCY OF EOSINOPHILIA AND RISK FACTORS AND THEIR ASSOCIATION WITH ToxOcara INFECTION IN SCHOOLCHILDREN DURING A HEALTH SURVEY IN THE NORTH OF LIMA, PERU
}

\author{
William H. ROLDÁN(1), Yrma A. ESPINOZA(1), Arturo ATÚNCAR(2), Emperatriz ORTEGA(2), América MARTINEZ(2) \& Melissa SARAVIA(2)
}

\begin{abstract}
SUMMARY
During a health survey in a primary school from the district of Carabayllo (North of Lima, Peru), 200 schoolchildren (96 male and 104 female between five to 12 years old) were randomly selected and divided in two groups (as positive or negative group), according to the serologic result of the Toxocara ELISA test from a total population of 646 schoolchildren. All children were analyzed by hematologic tests to determinate the frequency of eosinophilia and leukocytosis. Additionally, all clinical and epidemiological data were also analyzed to determine their association with toxocariasis. From group of children with positive serology, $40 \%$ had some type of eosinophilia in contrast to $19 \%$ of children with negative serology, and their association was statistically significant $(\mathrm{OR}=2.84, p<0.001)$. From all signs and symptoms evaluated, only 'dry cough' was more frequent and statistically significant in the positive serology group $(\mathrm{OR}=2.79, p<0.001)$. Almost all risk factors evaluated were highly frequent and statistically associated to the positive serology. In conclusion, the presence of eosinophilia and the risk factors evaluated in this population were frequently associated to human toxocariasis.
\end{abstract}

KEYWORDS: Toxocara; Toxocariasis; ELISA; Eosinophilia; Risk factors.

\section{INTRODUCTION}

Human toxocariasis is an accidental parasitic disease due to infection by larval stages of Toxocara canis and T. cati, the common roundworms of dogs and cats, respectively ${ }^{15}$. The adult forms live in the upper intestinal tract of their definitive hosts and can produce about 200,000 eggs per day and are excreted into the environment with their feces ${ }^{29}$. Toxocara eggs usually become infective within two to five weeks and have been isolated in backyard soil, parks, playgrounds, and other public places around the world ${ }^{15,29}$.

Humans become infected by ingesting either embryonated eggs from soil, dirty hands or raw vegetables and these eggs hatch to release larvae that penetrate the small intestine, enter the circulatory system, and invade several organs, including liver, heart, lungs, eyes, brain and other tissues. In most cases, their migration causes an intense inflammatory response and eosinophilia ${ }^{15,29}$.

Visceral and ocular toxocariasis (VLM and OLM, respectively) are two primary clinical syndromes associated with Toxocara infection. VLM is a severe systemic form of toxocariasis, characterized by high eosinophilia, hypergammaglobulinemia, fever, hepatosplenomegaly, and lung involvement and affect mainly children ${ }^{6,29}$.

OLM is due to intraocular infection and their manifestations include chorioretinitis, optic papillitis, endophthalmitis, and keratitis and can lead to permanent partial or complete loss of vision ${ }^{29,38}$. VLM and OLM are reported in the medical literature for many years, but there are discrepancies among the low frequencies of disease and the high values of seroprevalence reported in apparent healthy people. This gives an idea about the existence of other forms of toxocariasis, whose clinical forms are very unspecific and distinct of the classics VML and OLM syndromes ${ }^{29,33}$.

In helminthic diseases, moderate to severe eosinophilia occurs as a pathophysiologic response to the parasitic infection ${ }^{25}$ and it has been recognized that toxocariasis might be the main cause of eosinophilia, regardless of the presence of signs and symptoms or organ injuries $^{26}$. However, a peripheral eosinophilia is not always specific for toxocariasis ${ }^{29}$.

In order to know the association among peripheral eosinophilia, clinical signs and symptoms, and serology for Toxocara, the aim of the present study was to determinate the frequency of eosinophilia and risk factors and their association with toxocariasis in schoolchildren during a health survey in the North of Lima, Peru.

\section{MATERIAL AND METHODS}

From May to August 2006, a total population of 646 schoolchildren participated in a gratuitous health promotion carried out in the district

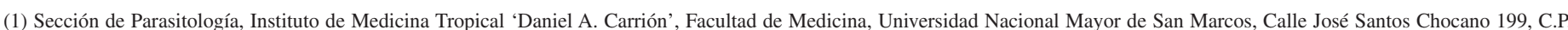
10138, Callao, Perú.

(2) Escuela Académico Profesional de Tecnología Médica, Facultad de Medicina, UNMSM, Av. Grau 755, Lima, Perú.

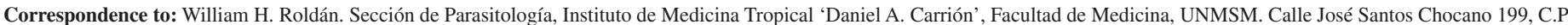
10138, Callao, Perú. Tel: +511 - 6197000 anexo 4404. E-mail: willyroldan23@ hotmail.com 


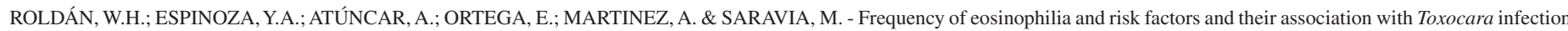
in schoolchildren during a health survey in the north of Lima, Peru. Rev. Inst. Med. trop. S. Paulo, 50(5): 273-278, 2008.

of Carabayllo (North of Lima city, Peru), as part of the community health promotion services. This health promotion included medical, parasitological and immunological examinations. Additionally, all the participants were previously interviewed using an individual clinicalepidemiological questionnaire plus a free informed consent signed by their parents. The anamnesis data, clinical signs and symptoms (lung involvement, bronchospasms, bronchitis, asthma, chronic weakness, hepato and splenomegaly, rash, abdominal pain, muscle pain, strabismus, retinitis, visual loss, convulsions and other signs of central nervous system involvement); epidemiological data and risk factors (age, sex, ownership of dogs or/and cats, their presence within the home, presence of house gardens and its use in child games, use of public parks, history of pica and/or geophagia). The clinical interview, the individual questionnaire, as well as the use of biological fluid samples stocked at our institution had the approval of the Ethical Research Committee of the Faculty of Medicine, UNMSM.

All sera from the child school population interviewed were analyzed by a Toxocara ELISA-IgG test (see below) and the total frequency for anti-Toxocara antibodies was 31.1\% (201/646). Then, two groups of 100 children were randomly selected for the hematological study, according to the serological result of the ELISA test (positive or negative).

The Toxocara ELISA-IgG test was carried out according to procedures of ROLDÁN et al. ${ }^{35}$ at a serum dilution of 1:200. The cut-off value was set by the mean optical density (OD) of the negative reference serum, plus three standard deviations. Serum samples with OD above of cut-off value were considered as positive. Additionally, all positive sera were serially two-fold diluted to determine antibody concentration by titration.

For hematological examination, heparinized blood samples were collected and all routine laboratorial examinations were included (total erythrocyte and leukocyte count, leukocyte differential formula, hemoglobin and hematocrit). Leukocytosis was defined as cell count more than 10,000 cells $/ \mu \mathrm{L}$ and the eosinophilia was defined as absolute eosinophils count more than 500 cells $/ \mu \mathrm{L}^{45}$ and classified as normal $(<$ $6 \%$ ), mild (6-10\%), moderate (11-15\%) and severe (>15\%) eosinophilia. Additionally, parasitological examination in stool samples was realized to detect intestinal parasites that can generate cross-reactions with the ELISA test.

All data were introduced in an Excel spreadsheet and statistical analysis was carried out using the program Epi-Info version 6.0. Chisquare test and Odds Ratio (OR) were performed to confirm the difference between groups. The level of significance selected was $p<0.05$.

\section{RESULTS}

A total of 200 children (96 male and 104 female) were evaluated and their mean age was $7.35 \pm 1.49$ years old (range $5-12$ years old). The mean OD value for the children group with positive serology was 0.905 \pm 0.196 (range 0.611-1.393) and for the children group with negative serology was $0.1898 \pm 0.077$ (range $0.09-0.296$ ). From 100 children with positive serology, $48 \%$ had titers of $200,26 \%$ had titers of $400,18 \%$ had titers of 800 , and $8 \%(2 / 59)$ had titers of 1600 .
The mean of total erythrocytes count was 4,285,000 $\pm 1,874,000$ cells $\mu \mathrm{L}$ (range 3,930,000 - 6,730,000 cells $/ \mu \mathrm{L}$ ), total leukocytes count was $13,234.6 \pm 6,642.3$ cells/ $\mu \mathrm{L}$ (range 3,750 - 23,700 cells/ $\mu \mathrm{L}$ ), and eosinophils count was $1,650.9 \pm 453.5$ cells $/ \mu \mathrm{L}$ (range $55-2310$ cells $/ \mu \mathrm{L}$ ). Neither of studied schoolchildren took low levels of hemoglobin (normal levels $=11.5-14.5 \mathrm{~g} / \mathrm{dL})$ or hematocrit (normal levels $=37-39 \%)$.

From group of children with positive serology, $57 \%$ had leukocytosis and $40 \%$ had some type of eosinophilia (28\% had mild eosinophilia, $9 \%$ had moderate eosinophilia, and $3 \%$ had severe eosinophilia) and its association was statistically significant (Chi-square $=10.6 ; p=0.0011$; $\mathrm{OR}=2.84$ ). In contrast, children group with negative serology, $38 \%$ had leukocytosis and $19 \%$ had some type of eosinophilia (18\% had mild eosinophilia, and $1 \%$ had moderate eosinophilia).

In both studied groups, various children were found to have signs or symptoms related with toxocariasis. However, only the presence of 'dry cough' were statistically significant in patients with positive serology (Chi-square $=9.96 ; p=0.0016 ; O R=2.79)$. All record of signs and symptoms evaluated in this study are shown in the Table 1.

Almost all risk factors for toxocariasis were significant in relation to the serology, except for 'presence of dogs and cats within the house' (Chi-square $=2.12 ; p=0.1452 ; O R=1.53)$ and 'playing with dogs and cats' (Chi-square $=1.06 ; p=0.3039 ; O R=1.35)$ that was not statistically significant (Table 2).

The parasitological study revealed that $32 \%$ of children with positive serology had some intestinal pathogen parasite $(28 \%$ had Blastocystis hominis, $10 \%$ has Giardia lamblia, $1 \%$ had Cyclospora cayetanensis, and $1 \%$ had Enterobius vermicularis) in contrast to $24 \%$ of children with negative serology (21\% had B. hominis, and $8 \%$ has G. lamblia). However the relationship between intestinal parasites and serology for Toxocara was not statistically significant (Chi-square = $1.59 ; p=0.2077 ; O R=1.49$ ).

\section{DISCUSSION}

Human toxocariasis is still a poorly diagnosed disease, especially in places with conditions, which favors its development, and it is largely unknown either to health professionals or the general population.

Previously, we observed $31.1 \%$ of frequency for anti-Toxocara antibodies in this child population using an ELISA-IgG test, suggesting that this child population had contact with the parasite, and developed an immune response with production of specific antibodies. This value is similar in comparison with other studies carried out in our country ${ }^{16,17}$ and in other Latin American countries ${ }^{1,2,4,31,34}$.

After the hematological analysis of the two groups of children (ELISA positive group and ELISA negative group), we have found that $40 \%$ of the ELISA positive group had eosinophilia with a significant association to the serology $(p=0.0011)$. However, $19 \%$ of the ELISA negative group also had some type of eosinophilia. In both groups, a mild eosinophilia was predominantly found indicating a possible eosinophilia due to Toxocara infection as reported by other authors ${ }^{12,13,23,26}$.

Although it is known that allergic, malignant and infectious diseases 


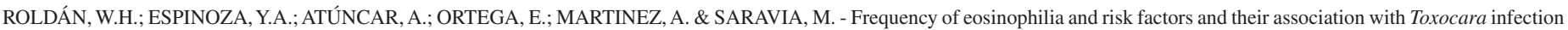
in schoolchildren during a health survey in the north of Lima, Peru. Rev. Inst. Med. trop. S. Paulo, 50(5): 273-278, 2008.

TABLE 1

Distribution of signs and symptoms as related to Toxocara serology in schoolchildren from district of Carabayllo, Lima, Peru, 2006

\begin{tabular}{|c|c|c|c|c|c|c|c|}
\hline \multirow{3}{*}{ Signs and symptoms } & \multicolumn{4}{|c|}{ Serology for Toxocara } & \multicolumn{3}{|c|}{ Statistics } \\
\hline & \multirow{2}{*}{$\begin{array}{l}\text { Positive } \\
(\mathrm{n}=100)\end{array}$} & \multirow{2}{*}{$\begin{array}{l}\text { Negative } \\
(\mathrm{n}=100)\end{array}$} & \multicolumn{2}{|c|}{ Total } & \multirow{2}{*}{ Chi-square } & \multirow{2}{*}{ OR } & \multirow{2}{*}{$p$} \\
\hline & & & $\mathrm{n}$ & $\%$ & & & \\
\hline Eosinophilia & 40 & 19 & 59 & 29.5 & 10.6 & 2.84 & 0.0011* \\
\hline Leukocytosis & 57 & 38 & 95 & 47.5 & 7.24 & 2.16 & $0.0071 *$ \\
\hline Dry cough & 38 & 18 & 56 & 28 & 9.96 & 2.79 & $0.0016 *$ \\
\hline Bronchitis & 14 & 8 & 22 & 11 & 1.84 & 1.87 & 0.1751 \\
\hline Asthma & 7 & 6 & 13 & 6.5 & 0.04 & 0.93 & 0.8489 \\
\hline Abdominal pain & 43 & 45 & 88 & 44 & 0.08 & 0.92 & 0.7757 \\
\hline Hepatosplenomegaly & 0 & 0 & 0 & 0 & N.A & N.A & N.A** \\
\hline Weight loose & 12 & 9 & 21 & 10.5 & 0.48 & 1.38 & 0.4889 \\
\hline Chronic weakness & 17 & 12 & 29 & 14.5 & 1.01 & 1.5 & 0.3153 \\
\hline Occasional fever & 15 & 14 & 29 & 14.5 & 0.04 & 1.08 & 0.8408 \\
\hline Rash & 14 & 12 & 26 & 13 & 0.18 & 1.19 & 0.6741 \\
\hline Muscle pain & 24 & 23 & 47 & 23.5 & 0.03 & 1.06 & 0.8676 \\
\hline Head pain & 33 & 26 & 59 & 29.5 & 1.18 & 1.4 & 0.2778 \\
\hline Convulsions & 2 & 0 & 2 & 1 & 0.34 & 2.02 & 0.5607 \\
\hline Visual loose & 13 & 12 & 25 & 12.5 & 0.05 & 1.1 & 0.8307 \\
\hline Photophobia & 15 & 14 & 29 & 14.5 & 0.04 & 1.08 & 0.8408 \\
\hline Ocular pain & 12 & 9 & 21 & 10.5 & 0.48 & 1.38 & 0.4889 \\
\hline
\end{tabular}

* Significant values; $p<0.05$; ** Non applicable.

Table 2

Distribution of risk factors as related to Toxocara serology in schoolchildren from district of Carabayllo, Lima, Peru, 2006

\begin{tabular}{|c|c|c|c|c|c|c|c|}
\hline \multirow{3}{*}{ Risk factors } & \multicolumn{4}{|c|}{ Serology for Toxocara } & \multicolumn{3}{|c|}{ Statistics } \\
\hline & \multirow{2}{*}{$\begin{array}{l}\text { Positive } \\
(\mathrm{n}=100)\end{array}$} & \multirow{2}{*}{$\begin{array}{l}\text { Negative } \\
(\mathrm{n}=100)\end{array}$} & \multicolumn{2}{|c|}{ Total } & \multirow{2}{*}{ Chi-square } & \multirow{2}{*}{ OR } & \multirow{2}{*}{$p$} \\
\hline & & & $\mathrm{n}$ & $\%$ & & & \\
\hline Dogs or cats within the home & 43 & 33 & 76 & 38 & 2.12 & 1.53 & 0.1452 \\
\hline Playing with dogs or cats & 40 & 33 & 73 & 36.5 & 1.06 & 1.35 & 0.3039 \\
\hline Gardens in the house & 45 & 31 & 76 & 38 & 4.16 & 1.82 & $0.0414 *$ \\
\hline Playing on house gardens & 57 & 29 & 86 & 43 & 15.99 & 3.25 & $0.0001 *$ \\
\hline Playing in public parks & 64 & 50 & 114 & 57 & 4 & 1.78 & $0.0455^{*}$ \\
\hline Pets in playgrounds & 62 & 41 & 103 & 51.5 & 8.83 & 2.35 & $0.003^{*}$ \\
\hline History of pica or geophagia & 78 & 57 & 135 & 67.5 & 10.05 & 2.67 & $0.0015 *$ \\
\hline
\end{tabular}

* Significant values; $\mathrm{p}<0.05$.

can cause an increase of eosinophils in peripheral blood, it is accepted that the most common cause of eosinophilia are parasitic infections. The parasitic diseases causing strong eosinophilia are schistosomiasis, filariasis, trichinosis, toxocariasis, and fasciolosis ${ }^{14,30,32,39,44}$. Furthermore, it is known that eosinophilia is very associated with toxocariasis in pediatric patients but there have been few studies about the relationship between toxocariasis and eosinophilia. On the other hand, the children with negative serology also presented a mild eosinophilia, which might be due to another tissue parasitic infection or an early Toxocara infection without positive serology, a possible allergy (also frequent in pediatric 


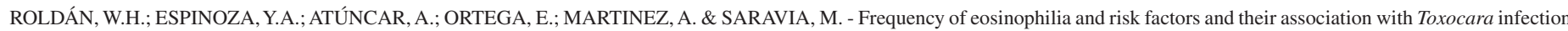
in schoolchildren during a health survey in the north of Lima, Peru. Rev. Inst. Med. trop. S. Paulo, 50(5): 273-278, 2008.

patients), a case of atopy, or other unknown causes.

The presence of signs and symptoms associated to positive serology indicates a Toxocara infection in pediatric patients, as reported by many authors ${ }^{15,17,29,33}$. However, we almost not found evidences of clinical signs or symptoms suggestive to Toxocara infection in this child population, except for 'dry cough' that was statistically significant and more frequent in the seropositive group than in the seronegative group ( $p=0.0016$ ). These data suggest that this studied population could be presenting an unapparent or covert toxocariasis ${ }^{33,40,41}$, due to unspecific clinical manifestations and the mild eosinophilia so different from classic syndromes of VLM and OLM.

Many studies have shown that the risk factors are very important in the epidemiology of toxocariasis, mainly the presence of dogs and cats living together with the people. However, in this study, we have not found some relationship between playing with dogs or cats, in agreement with other reported studies ${ }^{18,21}$ but contradicting the findings by CHIEFFI $e t$ $a l .{ }^{8}$ and SCHANTZ et al. ${ }^{36}$, who have reported a higher frequency of infection in individuals who were in contact with dogs.

The presence of dogs or/and cats within home tended to be associated with risk of infection by Toxocara ${ }^{37,46}$. However, in the present study, this association was not statistically significant $(p=0.1452)$, contradicting findings by CHIODO et al. ${ }^{11}$ and SCHANTZ et al. ${ }^{36}$ showing significant association between seropositivity and dogs or/and cats within the home.

Some studies have demonstrated that soil samples taken from gardens of homes where a clinical case of toxocariasis is found, are likely to be contaminated ${ }^{10,19,29}$. Toxocara eggs have been recovered from salads and other raw vegetables taken from such gardens ${ }^{43}$. In our study, we found a high significant association between having gardens and positive serology to Toxocara ( $p=0.0414)$. Few reports mention sampling of residential locations or specific areas, such as gardens, likely to be important in transmission $^{19}$. These areas are of special significance because of the potential for extensive use by humans and their pets.

In many cases, children tended to play inside gardens because their typical social behavior, resulting in increased exposure to the Toxocara eggs when the same gardens are used for defecations of pets ${ }^{10,19,29,36}$. In the present study, we have found a high significant association between playing on gardens and positive serology to Toxocara $(p=0.0001)$.

MAGNAVAL et al. ${ }^{29}$ reported that poor personal hygiene as well as consumption of raw vegetables grown in contaminated kitchen gardens may result in chronic low-dose infections.

Use of public parks for games is another important risk factor associated to toxocariasis infection because canine stools are very frequent in these places in many countries ${ }^{10,19,29}$. In our study, playing in public parks $(p=0.0455)$ and presence of pets in these places $(p=$ 0.003 ) had a significant association with Toxocara infection. It is possible that infection in children might have been brought about by inadvertent ingestion of Toxocara eggs contaminating soil of public parks within the district. Limited studies in our country on the contaminated soil with Toxocara eggs revealed a frequency ranging from $30 \%$ to $80 \%$. Furthermore, the proportion of soil samples positive for Toxocara eggs in parks and playgrounds from Latin American countries has ranged from 15 to $78 \%$.

Geophagia (eating soil) is a specific type of pica that increases the risk of toxocariasis, especially in children living in homes with puppies that have not been dewormed. In this study, we have found that this type of human behavior is significantly associated to Toxocara infection ( $p$ $=0.0015)$. Moreover, geophagia is the main characteristic associated to toxocariasis as reported in several studies around the world, since human toxocariasis has been described as a soil transmitted zoonosis $2,15,17,20,29$.

Systemic infection and high frequency of intestinal parasites occasionally might be found, but its statistical association between them is poor. As results show, more frequent parasites are protozoa and they do not cause cross-reactions with the ELISA test. However, these results suggest that this child population have been exposed to fecal contamination of food and poor hygiene; this is a principal way to get Toxocara infection and represent a characteristic from the studied group.

The frequency of human toxocariasis found in the present study could be the result of various factors, but doubtless, the most important are the rural and social characteristics of the district of Carabayllo, a town in the North of Lima with an extended area without paved streets and a deficient daily cleaning, with a medium percentage of population with unsatisfied basic needs and a high proportion of dogs living at home. It is well known that when dogs are present, the potential for household contamination with Toxocara eggs is high. Furthermore, deficient sanitary behaviors, climatic conditions and houses in poor neighborhoods, led to most of these children playing in close contact with soil since early ages.

Serological and epidemiological characteristics for Toxocara infection was observed in the present studied population. Future studies about soil contamination should be done to better assess the magnitude of this serious health problem, and community education programs should be developed to promote the social concept of a responsible pet ownership.

We can conclude from our study that human toxocariasis is a parasitic zoonosis with a wide range of unspecific clinical characteristics that has up to the present received little attention by the health community. Further studies will be required to ascertain the contribution of this parasitic disease to the overall morbidity of such populations.

\section{RESUMO}

\section{Freqüência de eosinofilia e fatores de risco e sua associação com infecção pela Toxocara em escolares, durante estudo epidemiológico no norte de Lima, Peru}

Durante estudo epidemiológico em escola primária do Distrito de Carabayllo (norte de Lima, Peru), 200 crianças (96 do sexo masculino e 104 do feminino, entre cinco e 12 anos de idade) foram selecionadas ao acaso e divididas em dois grupos (grupo positivo e grupo negativo) de acordo com os resultados de teste de ELISA para Toxocara em população total de 646 escolares. Todas as crianças foram analisadas por testes hematológicos para determinar a freqüência de eosinofilia e leucocitose. Adicionalmente, os dados clínicos e epidemiológicos foram analisados para determinar associação com toxocaríase. No grupo de crianças com sorologia positiva $40 \%$ tinham eosinofilia em contraste com $19 \%$ de 
ROLDÁN, W.H.; ESPINOZA, Y.A.; ATÚNCAR, A.; ORTEGA, E.; MARTINEZ, A. \& SARAVIA, M. - Frequency of eosinophilia and risk factors and their association with Toxocara infection in schoolchildren during a health survey in the north of Lima, Peru. Rev. Inst. Med. trop. S. Paulo, 50(5): 273-278, 2008

crianças com sorologia negativa e esta associação foi estatisticamente. significante $(\mathrm{OR}=2,84, p<0,001)$. De todos os sinais e sintomas avaliados, somente tosse seca foi mais freqüente e estatisticamente significante no grupo de sorologia positiva $(\mathrm{OR}=2,79, p<0,001)$. Quase todos os fatores de risco avaliados foram de alta frequiência e estatisticamente associados à sorologia positiva. Em conclusão, a presença de eosinofilia e dos fatores de risco avaliados nesta população foram frequentemente associados à toxocaríase humana.

\section{REFERENCES}

1. AGUdElo, C.; VillareAl, E.; CÁCERES, E. et al. - Human and dogs Toxocara canis infection in a poor neighborhood in Bogotá. Mem. Inst. Oswaldo Cruz, 85: 75-78, 1990 .

2. ALDERETE, J.M.S.; JACOB, C.M.A.; PASTORINO A.C. et al. - Prevalence of Toxocara infection in schoolchildren from the Butantã region, São Paulo, Brazil. Mem. Inst. Oswaldo Cruz, 98: 593-597, 2003.

3. ALONSO, J.M.; BOJANICH, M.V.; CHAMORRO, M. \& GORODNER, J.O. - Toxocara seroprevalence in children from a subtropical city in Argentina. Rev. Inst. Med. trop. S. Paulo, 42: 235-237, 2000.

4. ANARUMA FILHO, F.; CHIEFFI, P.P.; CORREA, C.R.S. et al. - Human toxocariasis: a seroepidemiological survey in the municipality of Campinas (SP), Brazil. Rev. Inst. Med. trop. S. Paulo, 44: 303-307, 2002

5. BARRIGA, O.O. - A critical look at the importance, prevalence and control of toxocariasis and the possibilities of immunological control. Vet. Parasit., 29: 195-234, 1988.

6. BEAVER, P.C.; SNYDER, C.H.; CARRERA, G.M.; DENT, J.H. \& LAFFERTY, J.W. Chronic eosinophilia due to visceral larva migrans: report of three cases. Pediatrics, 9: 7-19, 1952.

7. CHÁVEZ, A.; CASAS, E.; CAJAS, J. \& VELARDE, J. - Contaminación de parques públicos con huevos de Toxocara sp. en los distritos de la provincia constitucional del Callao y del cono sur de Lima metropolitana. Rev. Invest. Vet. Peru, 11: 52-57, 2000 .

8. CHIEFFI, P.P.; UEDA, M.; CAMARGO, E.D. et al. - Contato domiciliar e profissional com cães como fatores de risco para infecção humana por larvas de Toxocara. Rev. Inst. Med. trop. S. Paulo, 30: 379-382, 1988.

9. CHIEFFI, P.P.; UEDA, M.; CAMARGO, E.D. et al. - Visceral larva migrans: a seroepidemiological survey in five municipalities of São Paulo State, Brazil. Rev. Inst. Med. trop. S. Paulo, 32: 204-210, 1990.

10. CHILDS, J.E. - The prevalence of Toxocara species ova in backyards and gardens of Baltimore, Maryland. Amer. J. publ. Hlth, 75: 1092-1094, 1985.

11. CHIODO, P.; BASUALDO, J.; CIARMELA, L. et al. - Related factors to human toxocariasis in a rural community of Argentina. Mem. Inst. Oswaldo Cruz, 101: 397-400, 2006.

12. CHOI, J.H.; SUH, Y.J.; JUNG, J.W. et al. - Clinical significance of serum ECP and seroprevalence of human toxocariasis in patients with eosinophilia. J. Asth. Allergy clin. Immunol., 23: 26-32, 2003.

13. DEMIRCI, M.; KORKMAZ, M.; SAKRU, N.; KAYA, S. \& KUMAN, A. - Diagnostic importance of serological methods and eosinophilia in tissue parasites. J. HIth Popul. Nutr., 20: 352-355, 2002

14. DEMIRCI, M.; KORKMAZ, M.; KAYA, S. \& KUMAN, A. - Fasciolasis in eosinophilic patients in the Isparta region of Turkey. Infection, 31: 15-18, 2003.

15. DESPOMMIER, D. - Toxocariasis: clinical aspects, epidemiology, medical ecology, and molecular aspects. Clin. Microb. Rev., 16: 265-272, 2003.
16. ESPINOZA, Y.; HUAPAYA, P.; SEVILLA, C. \& HUIZA, A. - Toxocariosis humana seroprevalencia en la población de Lima mediante la técnica de ELISA. An. Fac. Med. (Lima), 64: 228-232, 2003.

17. ESPINOZA, Y.A.; HUAPAYA, P.H.; ROLDÁN, W.H. et al. - Clinical and serological evidence of Toxocara infection in school children from Morrope District, Lambayeque, Peru. Rev. Inst. Med. trop. S. Paulo, 50: 101-105, 2008.

18. GLICKMAN, L.T. \& CYPESS, R.H. - Toxocara infection in animal hospital employees Amer. J. publ. HIth, 67: 1193-1195, 1977.

19. HOLLAND, C.; O'CONNOR, P.; TAYLOR, M.R. et al. - Families, parks, gardens and toxocariasis. Scand. J. infect. Dis., 23: 225-231, 1991.

20. IDDAWELA, D.R.; KUMARASIRI, P.V. \& de WIJESUNDERA, M.S. - A seroepidemiological study of toxocariasis and risk factors for infection in children in Sri Lanka. Southeast Asian J. trop. Med. publ. Hlth, 34: 7-15, 2003.

21. JACOBS, D.E.; WOODRUFF, A.W.; SHAH, A.I. \& PROLE, J.H. - Toxocara infections and Kennel workers. Brit. med. J., 1: 51, 1977.

22. JACQUIER, P.; GOTTSTEIN, B.; STINLEGIN, Y. \& ECKERT, J. - Immunodiagnosis of toxocariasis in humans: evaluation of a new enzyme-linked immunosorbent assay kit. J. clin. Microbiol., 29: 1831-1835, 1991

23. KARADAM, S.Y.; ERTUG, S.; ERTABAKLAR, H. \& OKYAY, P. - The comparison of IgG antibodies specific to Toxocara spp. among eosinophilic and non-eosinophilic groups. New Microbiol., 31: 113-116, 2008.

24. KIM, Y.H.; HUH, S. \& CHUNG, Y.B. - Seroprevalence of toxocariasis among healthy people with eosinophilia. Korean J. Parasit., 46: 29-32, 2008

25. KLION, A.D. \& NUTMAN, T.B. - The role of eosinophils in host defense against helminth parasites. J. Allergy clin. Immunol., 113: 30-37, 2004

26. KWON, N.-H.; OH, M.-J.; LEE, S.-P. \& CHOI, D.C. - The prevalence and diagnostic value of toxocariasis in unknown eosinophilia. Ann. Hemat., 85: 233-238, 2006.

27. LESCANO, S.A.Z.; CHIEFFI, P.; PERES, B. et al. - Soil contamination and human infection by Toxocara sp. in the urban area of Lima, Peru. Mem. Inst. Oswaldo Cruz, 93: 733-734, 1998.

28. LYNCH, N.R.; EDDY, K.; HODGEN, A.N.; LOPEZ, R.I. \& TURNER, K.J. - Frequency of Toxocara canis infection in tropical Venezuela. Trans. roy. Soc. trop. Med. Hyg., 82: $275-281,1988$.

29. MAGNAVAL, J.F.; GLICKMAN, L.T.; DORCHIES, P. \& MORASSIN, B. - Highlights of human toxocariasis. Korean J. Parasit., 39: 1-11, 2001.

30. MELTZER, E.; PERCIK, R.; SHATZKES, J.; SIDI, Y. \& SCHWARTZ, E. - Eosinophilia among returning travelers: a practical approach. Amer. J. trop. Med. Hyg., 78: 702 709,2008 .

31. PALUDO, M.L.; FALAVIGNA, D.L.; ELEFANT, G.R. et al. - Frequency of Toxocara infection in children attended by the health public service of Maringá, south Brazil Rev. Inst. Med. trop. S. Paulo, 49: 343-348, 2007.

32. PARSONS, J.C. - Ascarid infections of cats and dogs. Vet. Clin. North. Anim. Pract. 17: 1307-1339, 1987.

33. PAWLOWSKI, Z. - Toxocariasis in humans: clinical expression and treatment dilemma J. Helminth., 75: 299-305, 2001

34. RADMAN, N.E.; ARCHELLI, S.M.; FONROUGE, R.D.; GUARDIS, M. \& LINZITTO, O.R. - Human toxocariasis. Its frequency in the city of La Plata. Mem. Inst. Oswaldo Cruz, 95: 281-285, 2000.

35. ROLDÁN, W.; CORNEJO, W. \& ESPINOZA, Y. - Evaluation of the dot-ELISA in comparison with standard ELISA for the immunodiagnosis of human toxocariasis Mem. Inst. Oswaldo Cruz, 101: 71-74, 2006. 
ROLDÁN, W.H.; ESPINOZA, Y.A.; ATÚNCAR, A.; ORTEGA, E.; MARTINEZ, A. \& SARAVIA, M. - Frequency of eosinophilia and risk factors and their association with Toxocara infection in schoolchildren during a health survey in the north of Lima, Peru. Rev. Inst. Med. trop. S. Paulo, 50(5): 273-278, 2008.

36. SCHANTZ, P.M.; WEIS, P.E.; POLLARD, Z.F. \& WHITE, M.C. - Risk factors for toxocaral ocular larva migrans: a case-control study. Amer. J. publ. HIth, 70: 12691272,1980 .

37. SCHANTZ, P.M. - Toxocara larva migrans now. Amer. J. trop. Med. Hyg., 41 (suppl. 3): 21-34, 1989.

38. SHIELDS, J.A. - Ocular toxocariasis. A review. Surv. Ophthalmol., 28: 361-381, 1984.

39. TAKAMOTO, M.; WANG, Z.X.; WATANABE, N. et al. - Eosinophilia, IgE production, and cytokine production by lung $\mathrm{T}$ cells in surface $\mathrm{CD} 4$-deficient mutant mice infected with Toxocara canis. Immunology, 95: 97-104, 1998.

40. TAYLOR, M.R.; KEANE, C.T.; O'CONNOR, P.; GIRDWOOD, R.W. \& SMITH, H. Clinical features of covert toxocariasis. Scand. J. infect. Dis., 19: 693-696, 1987.

41. TAYLOR, M.R.; KEANE, C.T.; O'CONNOR, P.; MULVIHILL, E. \& HOLLAND, C. The expanded spectrum of toxocaral disease. Lancet, 1 (8587): 692-694, 1988.
42. THOMPSON, D.E.; BUNDY, D.A.P.; COOPER, E.S. \& SCHANTZ, P.M. Epidemiological characteristics of Toxocara canis zoonotic infection of children in a Caribbean community. Bull. Wld HIth Org., 64: 283-290, 1986.

43. VAZQUEZ, T.O.; MARTINEZ, B.I.; TAY, Z.J.; RUIZ, H.A. \& PEREZ, T.A. - Verdura de consumo humano como probable fuente de infección de Toxocara sp. para el hombre. Bol. chil. Parasit., 52: 47-50, 1997.

44. VIJAYAN, V.K. - Tropical pulmonary eosinophilia: pathogenesis, diagnosis and management. Curr. Opin. Pulm. Med., 13: 428-433, 2007.

45. WILLIAMS, W.J.; BEUTLER, E.; ERSLEV, A.J. \& LICHTMAN, A.M. - Hematology. 4. ed. New York, Mc Graw-Hill, 1991. p. 1832-1833.

46. WOLFE, A. \& WRIGHT, I.P. - Human toxocariasis and direct contact with dogs. Vet. Rec., 152: 419-422, 2003.

Received: 6 July 2008

Accepted: 2 September 2008 